\title{
PELATIHAN PENELITIAN TINDAKAN KELAS (PTK) BAGI GURU SMK DI DEPOK
}

\author{
Nurul Frijuniarsi ${ }^{1)}$, Natalia Tri Astuti ${ }^{2)}$, Rosdiana ${ }^{3)}$ \\ Fakultas Teknik dan MIPA, Universitas Indraprasta PGRI \\ frijuniarsinurul@gmail.com,natnatalia.lia@gmail.com
}

\begin{abstract}
Abstrak
Profesi guru menuntut setiap individu yang berkecimpung di dalamnya untuk selalu berimprovisasi dalam meningkatkan profesionalisme guna meraih kualitas pengajaran yang lebih baik, salah satunya dengan melaksakan Penelitian Tindakan Kelas (PTK), namun sayangnya tidak semua guru secara rutin melakukan PTK dikarenakan kurangnya pengetahuan akan prosedur pelaksanaannya. Tujuan dari pelaksanaan kegiatan pengabdian kepada masyarakat ini adalah untuk memberikan pelatihan Penelitian Tindakan Kelas (PTK) kepada guru di SMKN 2 Depok, khususnya dalam merencanakan, menyusun, melaksanakan, dan mengevaluasi untuk menunjang profesionalisme guru. Dengan pemberian pelatihan serta pendampingan penyusunan proposal, mitra mampu menghasilkan proposal Penelitian Tindakan Kelas sesuai dengan bidang masingmasing
\end{abstract}

Keywords: Pelatihan, PTK, Guru, SMK.

\begin{abstract}
A teacher profession makes everyones involved to improve their professionalism in order to reach the better quality of teaching, managing a Class Action Reasearch (PTK) is one of the solutions. Unfortunately not every teacher actualizes it as routine activity due to the lack of information about the procedures. The aim of this activity is to help the teachers of State Vocational High School 2 Depok to design, arrange, manage, and evaluate the class action research by giving them a full day training. With the team's guidance, the participants were able to construct the proposal for their research.
\end{abstract}

Keywords: Training, action research, Vocational high school.

\section{PENDAHULUAN}

Peningkatan kualitas pendidikan merupakan sebuah tantangan yang harus dihadapi oleh para tenaga pendidik di Indonesia. Hal ini tidak terlepas dari peran langsung guru sebagai ujung tombak pendidikan dan pengajaran di kelas. Seorang guru dituntut untuk bisa memberikan pengajaran yang baik bagi para peserta didiknya. Seorang guru yang baik seyogyanya mampu mencipta- kan kondisi dan lingkungan belajar yang kondusif sehingga memudahkan peserta didik dalam menyerap ilmu dan informasi yang diberikan, oleh karena itu, pemerintah memberikan apresiasi kepada para guru yang mampu menciptakan suasana belajar yang nyaman melalui metode-metode yang yang variatif dan efektif sebagai bentuk dukungan kepada guru untuk terus meningkatkan kemapuan mereka dalam melakukan tugas mengajar di kelas. Menurut Permenegpan \& RB Nomor 16 
tahun 2009, tentang Jabatan Fungsional Guru dan Angka Kreditnya, guru wajib dinilai kinerjanya dan melaksanakan kegiatan Pengembangan Keprofesian Berkelanjutan (PKB). Salah satu kegiatan PKB yang dapat dilakukan oleh guru adalah melaksanakan penelitian. Untuk mewujudkan hal tersebut guru harus mempunyai kemampuan meneliti, khususnya Penelitian Tindakan (Legiman, 2015)

Penelitian Tindakan Kelas (PTK) merupakan penelitian yang dapat dirasakan langsung manfaatnya oleh guru, karena sebagai seorang pengajar, kelas merupakan laboratorium eksperimen guru, yang erat dengan kesehariannya atau dengan kata lain mereka dapat melakukan penelitian tanpa pergi ke tempat lain (Sukardi, 2011 dalam Nurizzati, 2014) Asumsi yang mendasari pelaksanaan penelitian tindakan adalah bahwa orang akan belajar dan mengembangkan pengetahuan dari pengalaman sendiri yang konkrit; melalui pengamatan dan refleksi dalam pengalaman tersebut; melalui pembentukan konsep abstrak dan generalisasi; serta dengan menguji implikasi konsep dalam situasi baru. Jadi, Penelitian Tindakan Kelas (PTK) sebenarnya bukanlah hal baru bagi dunia pendidikan terutama seorang guru. Seorang guru dituntut untuk melakukan penelitian, salah satunya adalah PTK. Selain untuk memperbaiki pembelajaran di kelas juga untuk mendapatkan nilai kum dalam penilaian kinerja guru profesional. (Nurizzati, 2014). Menyadari tingginya kebutuhan guru akan Penelitian Tindakan Kelas (PTK), maka tim dosen Universitas Indraprasta PGRI berinisiatif untuk memberikan pelatihan kepada guru-guru di SMKN 1 dan SMKN 2 Depok sebagai bentuk pelaksanaan salah satu poin dalam Tri Darma Perguruan Tinggi, pengabdian kepada masyarakat.
Secara umum tujuan dari pelaksanaan kegiatan pengabdian kepada masyarakat ini adalah untuk memberikan pelatihan Penelitian Tindakan Kelas (PTK) kepada guru di SMKN 2 Depok, khususnya dalam merencanakan, menyusun, melaksanakan, dan mengevaluasi untuk menunjang profesionalisme guru.

Mitra pada kegiatan Pengabdian Kepada Masyarakat ini adalah guru-guru di SMKN 2 Depok, dengan tidak terbatas oleh latar belakang keilmuan tertentu. Mitra memliki 81 guru yang terdiri dari 41 guru PNS yang 12 di antaranya sedang melaksanakan tugas pelatihan, serta 40 guru honorer yang sebagian besar berusia muda dan belum memiliki jam terbang yang mumpuni. Dari total guru yang ada, hanya sebagian kecil yang sudah pernah melakukan Penelitian Tindakan Kelas karena kurangnya pengetahuan tentang prinsip dan tata cara pelaksanaan PTK, sementara penelitihan itu pada dasarnya dibutuhkan untuk menunjang profesionalisme serta fungsionalisme guru serta merupakaan salah satu komponen penilaian yang dibutuhkan dalam peningkatan jenjang kepangkatan seorang guru. Beranjak dari kondisi yang telah diuraikan sebelumnya, tim dosen pelaksana pengabdian kepada masyarakat menawarkan sebuah pelatihan pelaksanaan Penelitian Tindakan Kelas (PTK) kepada guru-guru di SMKN 2 Depok. Pelatihan ini akan difokuskan pada proses PTK mulai dari persiapan, pelaksanaan, sampai dengan penyusunan laporan.

Target yang ingin dicapai dari pelatihan ini adalah guru-guru di SMKN 2 Depok mampu melaksanakan Penelitian Tindakan Kelas sesuai dengan prosedur, mulai dari tahap penyusunan proposal, pelaksanaan penelitian, serta penyusunan laporan kegiatan Penelitian Tindakan Kelas (PTK). Sementara luaran umum yang diharapkan dapat 
dihasilkan dari pelatihan PTK ini adalah agar guru-guru di SMKN 2 Depok memiliki pengetahuan serta keterampilan dasar mengenai pelaksanaan Penelitian Tindakan Kelas (PTK) untuk kemudian dikembangkan sendiri, sehingga pada akhirnya tercapailah sebuah peningkatan atau perbaikan (improvement and theraphy), antara lain sebagai berikut: (1) Peningkatan atau perbaikan terhadap kinerja belajar siswa di sekolah. (2) Peningkatan atau perbaikan terhadap mutu proses pembelajaran di kelas. (3) Peningkatan atau perbaikan terhadap kualitas penggunaan media, alat bantu belajar, dan sumber belajar lainnya. (4) Peningkatan atau perbaikan terhadap kualitas prosedur dan alat evaluasi yang digunakan untuk mengukur proses dan hasil belajar siswa. (5) Peningkatan atau perbaikan terhadap masalah-masalah pendidikan anak di sekolah. (6) Peningkatan dan perbaikan terhadap kualitas penerapan kurikulum dan pengembangan kompetensi siswa di sekolah. Selain itu luaran yang dihasilkan pada kegiatan pengabdian kepada masyarakat ini dapat adalah sebuah produk berupa panduan pelaksanaan Penelitian Tindakan Kelas yang sekiranya dapat bermanfaat bagi guru pada umumnya, serta praktisi pendidikan yang ingin melasanakan Penelitian Tindakan Kelas kedepannya. Tim pelaksana juga berharap bahwa laporan kegiatan pengabdian kepada masyarakat ini dapat dipublikasikan sehingga dapat menjadi alternatif rujukan di kemudian hari.

Penelitian Tindakan Kelas (PTK) sebenarnya merupakan pengembangan dari penelitian tindakan (action research). Kemmis dan Taggart (1988) dalam Legiman (2015) menerangkan bahwa penelitian tindakan (action research) adalah suatu bentuk penelitian refleksi diri yang dilakukan oleh para partisipan dalam situasi sosial (termasuk pendidikan) untuk memperbaiki praktik yang dilakukan sendiri. Dengan demikian, akan diperoleh pemahaman yang komprehensif mengenai praktik dan situasi di mana praktik tersebut dilaksanakan. Terdapat dua hal pokok dalam penelitian tindakan yaitu perbaikan dan keterlibatan. Hal ini akan mengarahkan tujuan penelitian tindakan ke dalam tiga area yaitu; (1) untuk memperbaiki praktik; (2) untuk pengembangan profesional dalam arti meningkatkan pemahaman para praktisi terhadap praktik yang dilaksanakannya; serta (3) untuk memperbaiki keadaan atau situasi di mana praktik tersebut dilaksanakan. Dalam bidang pendidikan, penelitian tindakan (action research) kemudian dikhususkan dengan menambahkan kata kelas sebagai analogi ruang lingkup di mana pengajaran dan pendidikan dilaksanakan, tentu saja kata kelas yang dimaksudkan tidak lah selalu ruang kelas secara harfiah, melainkan dimana saja yang terjadi proses belajar mengajar misalnya laboratorium, karyawisata, ataupun tempat lain yang melibatkan sekelompok siswa dibawah arahan guru. (Nurizzati, 2014). Lebih lanjut, PTK dapat didefinisikan sebagai bentuk kajian yang bersifat reflektif, yang dilakukan oleh pelaku tindakan untuk meningkatkan kemantapan rasional dari tindakan-tindakannya dalam melaksanakan tugas dan memperdalam pemahaman terhadap kondisi dalam praktek pembelajaran. (Hopkins,1993 dalam Nurizzati, 2014). Berdasarkan uraian-uraian yang disadur dari beberapa pakar ataupun peneliti yang telah tim pelaksana jabarkan sebelumnya, maka dapat disimpulkan bahwa Penelitian Tindakan Kelas (PTK) merupakan satu bentuk penelitian yang melibatkan tindakan langsung antara guru sebagai pengajar terhadap siswa sebagai target dengan dengan tujuan untuk mengevaluasi proses pengajaran 
yang sudah berjalan serta memperbaiki kekurangan-kekurangan dalam proses tersebut sehingga dicapai peningkatan kualitas pengajaran.

PTK dapat dikategorikan sebagai jenis penelitian kualitatif dan eksperimen. Dikategorikan sebagai penelitian kualitatif karena pada saat data dianalisis digunakan pendekatan kualitatif, tanpa ada perhitungan statistik. Dikatakan sebagai penelitian eksperimen, karena penelitian ini diawali dengan perencanaan, adanya perlakuan terhadap subjek penelitian, dan adanya evaluasi terhadap hasil yang dicapai sesudah adanya perlakuan. Ditinjau dari karakteristiknya, PTK setidaknya memiliki karakteristik antara lain: (1) didasarkan pada masalah yang dihadapi guru dalam instruksional; (2) adanya kolaborasi dalam pelaksanaannya; (3) penelitian sekaligus sebagai praktisi yang melakukan refleksi; (4) bertujuan memperbaiki dan atau meningkatkan kualitas praktek instruksional; (5) dilaksanakan dalam rangkaian langkah dengan beberapa siklus. (Legiman, 2014).

Adapun langkah atau prosedur yang harus dilakukan dalam melaksanakan Penelitian Tindakan Kelas (PTK) adalah sebagai berikut: PTK difokuskan pada empat kegiatan pokok yaitu (1) Planning, mencakup kegiatan identifikasi masalah, perumusan masalah serta analisi penyebab masalah (2) Acting, merupakan langkah eksekusi atau pelaksanaan lapangan di mana gur lah yang berperan sebagai agent of change bagi dirinya dan kelas melalui tindakan praktis (3) Observing, melibatkan kegiatan pengumpulan data beserta analisis data temuan (4) Reflecting, adalah kegiatan mengulas secara kritis (reflective) tentang perubahan yang terjadi pada siswa, suasana kelas, dan guru. (Arikunto, 2009 dalam Nurizzati, 2011)

\section{METODE PELAKSANAAN}

Kegiatan pengabdian kepada masyarakat ini dilaksanakan selama empat bulan terhitung sejak bulan September sampai dengan Desember, yang terbagi menjadi dua tahap, yaitu tahap perdisapan dan tahap pelaksanaan. Tahap persiapan meliputi identifikasi kebutuhan, perijinan, dan pengadaan media pembelajaran

1. Identifikasi kebutuhan. Dalam tahap ini dilakukan identifikasi untuk mendapatkan gambaran tentang kondisi guru-guru di SMKN 2 Depok termasuk kebutuhan-kebutuhan yang nantinya melahirkan gagasan pelatihan ini.

2. Perijinan. Dalam tahap ini dilakukan permohonan ijin dari pihak ketua atau pimpinan kepada pihak SMKN 2 Depok.

3. Pengadaan media pelatiahan, dalam hal ini persiapan alat serta metode yang akan digunakan dalam pelatihan.

Pelaksanaan pelatihan dilaksanakan sebanyak dua kali pertemuan dengan durasi satu kali pertemuan selama 2 jam. Pada pertemuan pertama peserta diberikan pengenalan tentang hakikat dari Penelitian Tindakan Kelas (PTK) beserta tata cara pelaksanaan dan hal-hal yang harus diperhatikan dalam Penelitian Tindakan Kelas (PTK). Pada pertemuan selanjutnya peserta akan diberikan waktu untuk latihan menyusun proposal dan menyusun laporan akhir Penelitian Tindakan Kelas. Evaluasi dilakukan pada setiap tahap pelaksanaan kegiatan. Tahap ini meliputi evaluasi pada semua proses kegiatan yaitu mulai dari tahap persiapan sampai dengan tahap pelaksanaan kegiatan. Tahap evaluasi ini dilanjutkan dengan kegiatan penyusunan laporan. 


\section{HASIL DAN PEMBAHASAN}

Proses pelaksanaan program iptek bagi masyarakat ini secara umum dapat dikatakan berjalan dengan cukup lancar, dimulai dari tahap persiapan sampai dengan tahap pelaksanaan. Dalam tahap persiapan, tim pelaksana menganalisis kelebihan dan kekurangan dari masingmasing mitra (dalam hal ini dua jurusan mitra yang menjadi mitra adalah jurusan Teknik Audio-video, dan Jasa Boga di SMKN 2 Depok). Setelah mengetahui hal tersebut, maka tim pelaksana mencari solusi yang paling tepat untuk menutupi kekurangan demi kekurangan yang dapat teridentifikasi. Lalu tahap selanjutnya adalah memperkenalkan dan memberikan pelatihan penelitian tindakan kelas (PTK) bagi para guru. Dalam penelitian tindakan kelas terdapat beberapa prinsip yang perlu diperhatikan: (1) Tidak boleh mengganggu PBM dan tugas mengajar.

(2) Tidak boleh terlalu menyita waktu.

(3) Metodologi yang digunakan harus tepat. (4) Masalah yang dikaji benarbenar ada dan dihadapi guru. (5) Memegang etika kerja (minta izin, membuat laporan, dll). (6) Kemauan untuk berubah. (7) Kemampuan berfikir kritis dan sistematis. Apabila prinsip tersebut sudah cukup dipahami maka langkah selanjutnya adalah memperkenalkan langkah - langkah dalam penelitian tindakan kelas. Adapun langkah penelitian tindakan kelas adalah mengidentifikasi dan menganalisis masalah yang dihadapi guru dikelas, seperti: (1) Masalah apa yang akan diteliti, masalah harus benar-benar terjadi di kelas, penting dan bermanfaat dan berada dalam jangkauan si peneliti (guru). (2) Alasan mengapa penelitian tersebut dilakukan. (3) Cara yang digunakan untuk menemukan jawaban dari masalah tersebut. Hal ini dapat tercapai apabila baik tim pelaksana ataupun guru dapat saling berkomunikasi dengan baik dan terbuka mengenai permasalahan yang dihadapi sehingga dapat mencari solusi dengan lebih cepat dan tepat. Untuk hasil dan pembahasan yang lebih jelas, akan dipaparkan dalam penjelasan di masing-masing mitra.

\section{Teknik Audio-Video}

Proses pelaksanaan pengabdian kepada masyarakat bagi guru di jurusan Teknik Audio - video ini berjalan cukup baik dan menyenangkan. Hal ini dikarenakan antusias guru dalam mengikuti pelatihan dan diskusi yang menarik demi mencari solusi dari tiap permasalahan yang dihadapi dikelas. Pelaksanaan dimulai dengan memperkenalkan secara singkat apa itu penelitian tindakan kelas, tujuan dan dilanjutkan dengan langkah penelitian itu sendiri.

Setelah memperkenalkan dengan metode presentasi tentang penelitian tindakan kelas, pelatihan dilanjutkan dengan mencari permasalahan dan judul penelitian yang sesuai dengan permasalahan tersebut, kemudian guru diminta menyusun proposal penelitian. Dalam tahap ini, tim pelaksana mendampingi guru dalam pembuatan proposal hingga proposal itu selesai dan dapat dikatakan cukup baik dan layak untuk kemudian dilanjutkan dalam penelitian secara kongkrit. Hasil pelatihan guru yang berupa proposal kemudian dikumpulkan kepada tim pelaksana untuk ditinjau kembali dan diserahkan kepada kepala sekolah sebagai laporan bagi pihak sekolah atas terlaksananya kegiatan pelatihan penelitian tindakan kelas (PTK).

\section{Jasa Boga}

Proses pelaksanaan pengabdian kepada masyarakat bagi guru di jurusan Jasa Boga ini berjalan cukup baik, menyenangkan walau sedikit rumit. Hal ini dikarenakan guru pada jurusan ini 
sudah berusia cukup lanjut sehingga sulit untuk menggunakan alat teknologi dalam membuat proposal. Akan tetapi antusias guru dalam mengikuti pelatihan dan diskusi ini sangat menarik sehingga bersemangat dalam mencari solusi dari tiap permasalahan yang dihadapi dikelas. Pelaksanaan dimulai dengan memperkenalkan secara singkat apa itu penelitian tindakan kelas, tujuan dan dilanjutkan dengan langkah penelitian itu sendiri.

Setelah memperkenalkan dengan metode presentasi tentang penelitian tindakan kelas, pelatihan dilanjutkan dengan mencari permasalahan dan judul penelitian yang sesuai dengan permasalahan tersebut, kemudian guru diminta menyusun proposal penelitian. Dalam tahap ini, tim pelaksana mendampingi guru dalam pembuatan proposal hingga proposal itu selesai dan dapat dikatakan cukup baik dan layak untuk kemudian dilanjutkan dalam penelitian secara kongkrit. Hasil pelatihan guru yang berupa proposal kemudian dikumpulkan kepada tim pelaksana untuk ditinjau kembali dan diserahkan kepada kepala sekolah sebagai laporan bagi pihak sekolah atas terlaksananya kegiatan pelatihan penelitian tindakan kelas (PTK).

\section{Dokumentasi Kegiatan}

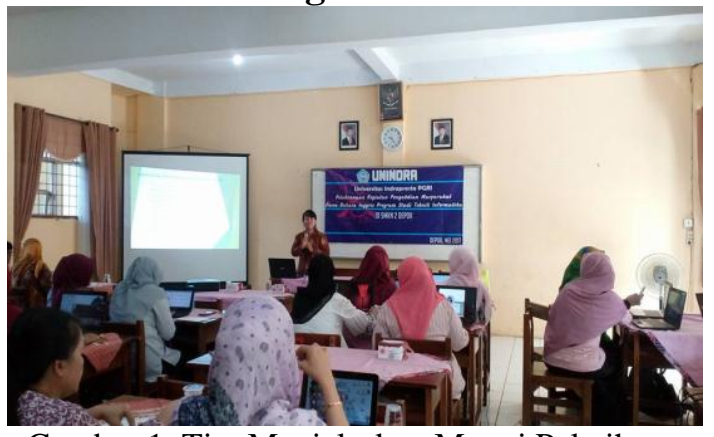

Gambar 1. Tim Menjelaskan Materi Pelatihan kepada Peserta.
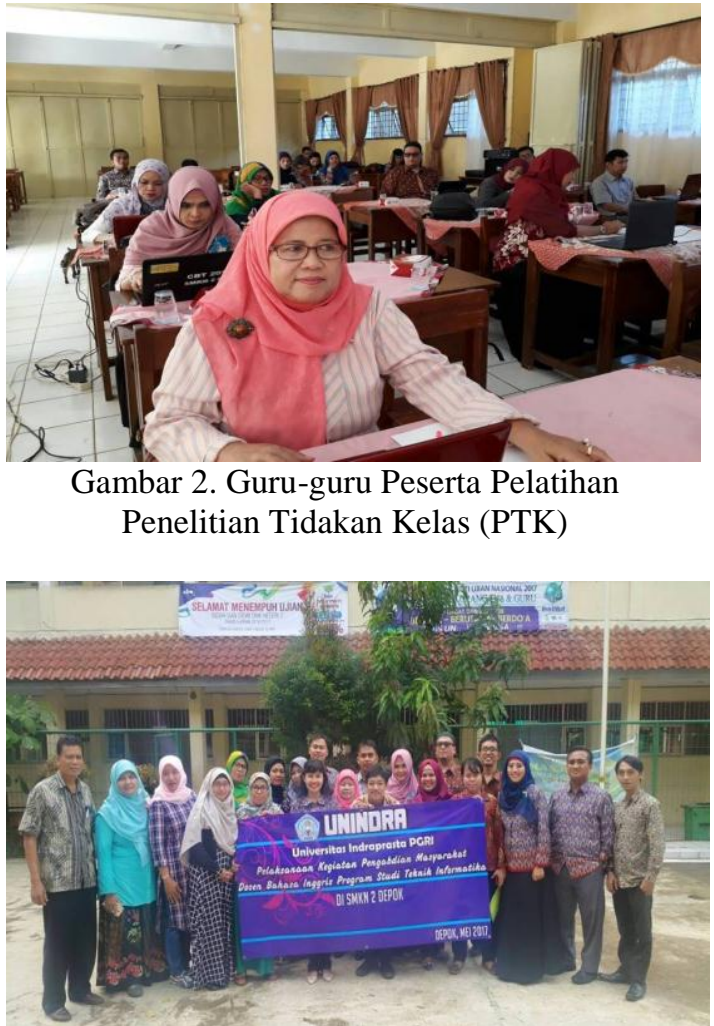

Gambar 3. Tim Dosen dan Beberapa Perwakilan Pihak Sekolah.

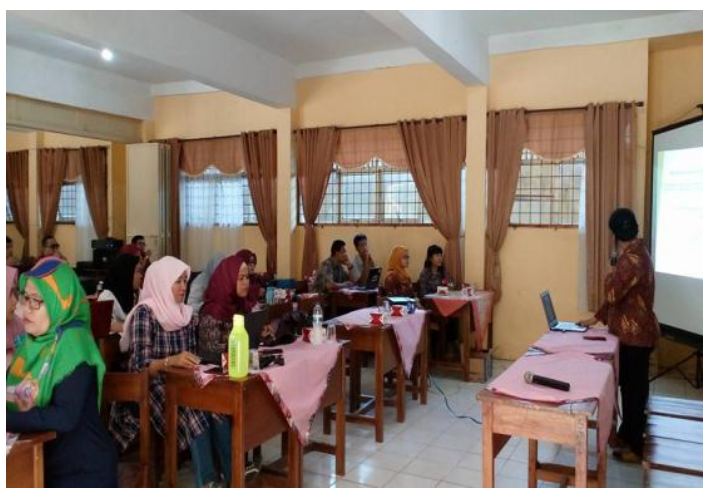

Gambar 4. Pendampingan Penyusunan Proposal PTK

\section{SIMPULAN}

Dalam pelaksanaan kegiatan pelatihan penelitian tindakan kelas (PTK) ini dapat disimpulkan bahwa:

1. Penelitian tindakan kelas merupakan hal yang diperlukan bagi para guru untuk membantu para guru jurusan Teknik Audio - video dan Jasa Bogadi SMKN 2 Depok merencanakan, menyusun, melaksanakan, dan mengevaluasi Penelitian Tindakan 
Kelas (PTK) untuk menunjang profesionalisme guru.

2. Tim pelaksana menyadari bahwa penelitian tindakan kelas (PTK) bukanlah proses yang sederhana dan singkat, diperlukan waktu yang cukup lama untuk memperoleh hasil yang sesuai. Dengan demikian kerjasama dari berbagai pihak sangat diperlukan untuk terlaksananya penelitian tindakan kelas, dan memperoleh hasil yang sesuai, sehingga dapat memberikan kontribusi bagi berbagai pihak khususnya bidang pendidikan.

Penelitian tindakan kelas dapat digunakan sebagai salah satu cara untuk meneliti, mengetahui dan mendapatkan solusi dari berbagai permasalahan yang terjadi di setiap kelas dalam proses belajar mengajar di setiap jenjang pendidikan. Kegiatan iptek bagi masyarakat ini pada dasarnya ditujukan untuk memberi wawasan dan juga pelatihan untuk melaksanakan penelitian tindakan kelas dalam upaya peningkatan profesionalisme para guru. Maka untuk kedepannya tim pelaksana berharap guru dapat melaksanakan segala proses penelitian tindakan kelas, mulai dari menemukan masalah, pembuatan proposal, pelaksanaan penelitian, hingga penyusunan laporan. Sehingga hasil penelitian yang didapat dapat memberikan kontribusi baik untuk kemajuan pendidikan di Indonesia.

\section{DAFTAR PUSTAKA}

Agustina, E.T. (2013). Implementasi Model Pembelajaran Snowball Throwing untuk Meningkatkan Hasil Belajar Siswa dalam Membuat Produk Kria Kayu dengan Peralatan manual. Jurnal INVOTEC Vol. IX No. 1. FPTK UPI bekerjasama dengan APTEKINDO: Bandung.

Ditjen Dikti. (2013). Pandun Pelaksanaan Penelitian dan Pengabdian Kepada Masyarakat di Perguruan Tinggi.Jakarta: Ditjen Dikti Depdiknas.

Legiman. (2015). Penelitian Tindakan Kelas. Widyaiswara LPMP: Yogyakarta

Nurizzati, Y. (2014). Ketertolakan Hasil Penelitian Tindakan Kelas. Jurnal Edueksos Vol III No. 1: Jurusan Tadris IPS FITK IAIN Syekh Nurjati: Cirebon

Rahmawati, D. (2012). Penelitian Tindakan Kelas. Diakses pada tanggal 20 Maret 2017 melalui http:/www.academia.edu/downloa d/35695504/penelitian-tindakankelas.pdf. 